\title{
Precision and accuracy of four current 3D Printers to achieve models for Fixed Dental Prosthesis
}

\author{
Bianca S. Reis' ${ }^{1}$ Fernando F. Portella'2, Elken G. Rivaldo' \\ ' Universidade Luterana do Brasil. Graduate Program in Dentistry, Canoas, RS, Brazil. \\ 2 Universidade Feevale, Novo Hamburgo, RS, Brazil.
}

\begin{abstract}
The aim of this study was to compare the accuracy and precision of $3 D$ printers used to obtain models of fixed dental prostheses. $A$ fixed dental prosthesis preparation was scanned and reproduced by four 3D printers: RapidShape P40, Asiga MAX, Varseo, and Photon. The impressions were scanned again, and the dataset was compared to the original dataset. Mean discrepancies $(\mu \mathrm{m})$ were 52.97 20.48 (RapidShape P40), $68.27 \pm 43.53$ (Asiga MAX),
\end{abstract}

$62.22 \pm 56.21$ (Varseo), and $80.03 \pm 28.67$ (Photon). There was no difference ( $p=0.314)$ in accuracy; however, the precision differed $(p=0.015)$ among the $3 D$ printers. The printers had distinct precision but did not differ in accuracy.

Received: November 2019; Accepted March 2020.

Keywords: dental models, dental prosthesis, three-dimensional printing.

\section{Precisão de quatro impressoras 3D para obtenção de modelos para prótese fixa}

\section{RESUMO}

O objetivo desse trabalho foi comparar a acurácia e a precisão de impressoras $3 D$ utilizadas para a obtenção de modelos para prótese fixa. Um preparo para prótese fixa foi escaneado e reproduzido por 4 impressoras 3D: RapidShape 3D, Asiga MAX, Varseo e Photon. As impressões foram novamente escaneadas, $e$ o dataset escaneado foi comparado ao original. Os escaneamentos foram sobrepostos digitalmente e determinada a discrepância entre os modelos original e impresso. A discre-

\section{INTRODUCTION}

The use of digital workflow in rehabilitation treatments is rapidly increasing. Given the practicality, biological safety, and comfort for the patient and health professional, this technology has gradually been replacing conventional workflow using stone models. Additive manufacturing (3D printing) enables the fabrication of provisional restorations and reliable preparations ${ }^{1}$. The accuracy and precision of these models are related to the final fit of prosthetic parts and, consequently, to the longevity of the restoration. Three-dimensional printers using the Direct Light Processing (DLP) technique have demonstrated good precision in obtaining dental models ${ }^{2}$. The impressions should be identical to the preparations (accuracy) and, if repeatedly printed, they should always have the same dimensions (precision). Recently, a wide pância média ( $\mu \mathrm{m})$ entre os modelos foi de foi $52,97 \pm 20,48$

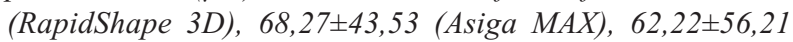
(Varseo) e 80,03 $\pm 28,67$ (Photon). Não houve diferença $(p=0,314)$ entre os valores médios, os quais representam a acurácia; entretanto, o desvio padrão dessas foi diferente $(0,015)$, indicando diferença na precisão das impressoras $3 D$.

Palavras-chave: modelos dentários, prótese dentária, impressão tridimensional.

variety of 3D printers has been introduced on the dental market, requiring technical assessments ${ }^{3}$. The present study was therefore designed to compare the accuracy and precision of four $3 \mathrm{D}$ printers used to obtain models of fixed dental prostheses.

\section{MATERIAL AND METHODS}

An acrylic resin model of a maxillary canine was prepared for a complete crown and then scanned (Trios, 3Shape S/A, Copenhagen, Denmark). Based on the generated dataset file (STL), models of the tooth were obtained from the impressions created using four $3 \mathrm{D}$ printers (Table 1). The specimens ( $\mathrm{n}=8$ for each printer) were scanned with a highprecision scanner (S600 ARTI, Zirkonzahn GmbH, Gais, Italy). The STLs that generated the impressions were superimposed on the STLs of the printed 
models using a specific software system (MeshLab 2016.12, Visual Computing Laboratory, Italy). Based on the overall superimposition prepared tooth, the discrepancies between the measurements were calculated by the Hausdorff method ${ }^{4}$ and then qualitatively categorized according to their location. Incisal, mesial, distal, buccal and lingual

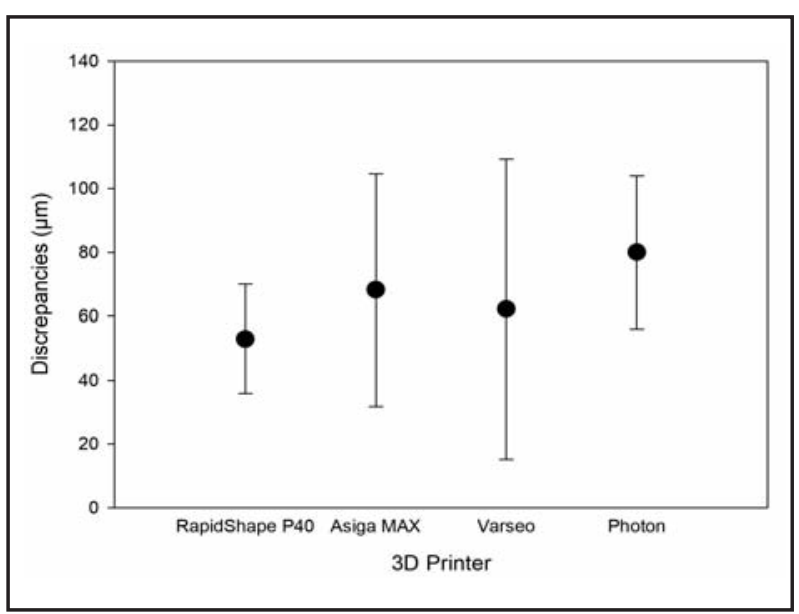

Fig. 1: Discrepancies $(\mu m) \pm$ standard deviation according to $3 D$ printer. The circle indicates the mean value (accuracy) and the whiskers indicate the 95\% confidence interval (precision). There was no difference in accuracy $(p=0.587)$, but precision varied among printers $(p=0.015)$.

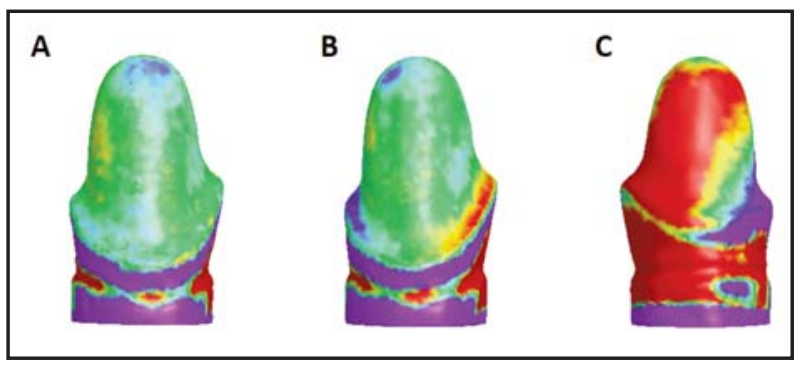

Fig. 2: Example of misfit (red areas) of models. A. no misfit; $B$. discrete misfit on the proximal surface; $C$. severe misfit on the buccal and proximal surfaces. areas were inspected for presence or absence of misfit (dichotomously, independently of the misfit area) and data were described in terms of misfit prevalence on each surface. The misfit was defined by the presence of red areas on superimposed images of original STL and STL of the printed models. Red areas mean that printed models are larger than original tooth. The mean overall discrepancy values of the 3D printed models were compared by Kruskal-Wallis test. The homogeneity of discrepancy variance was analyzed by the Levene test; differences in this analysis refer to the precision of the printer. The level of significance was set at $5 \%$ for all analyses.

\section{RESULTS}

The mean discrepancy $(\mu \mathrm{m})$ and standard deviations among the models were $52.97 \pm 20.48$ (RapidShape P40), 68.27 \pm 43.53 (Asiga MAX), 62.22 \pm 56.21 (Varseo), and $80.03 \pm 28.67$ (Photon), as shown in Fig. 1. Discrepancy values present a non-Gaussian distribution, and are shown in Table 1. There was no difference $(p=0.314)$ in mean values, which

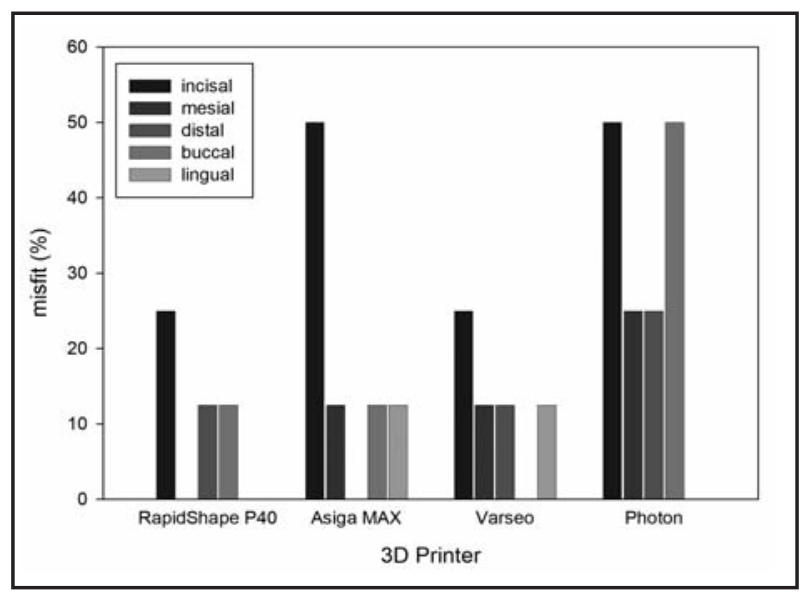

Fig. 3: Misfit (\%) of models according to $3 D$ printer and tooth surface.

Table 1: Detailed discrepancy values measured according printer evaluated.

\begin{tabular}{l|c|c|c|}
\hline Printer & Mean* $^{*} \mathbf{s d}^{\#}$ & Minimum discrepancy measured $(\boldsymbol{\mu m})$ & Maximum discrepancy measured $(\boldsymbol{\mu m})$ \\
\hline RapidShape P40 & $52.97 \pm 20.48$ & 31.86 & 84.65 \\
\hline Asiga MAX & $68.27 \pm 43.53$ & 29.59 & 126.57 \\
\hline Varseo & $62.22 \pm 56.21$ & 19.42 & 156.83 \\
\hline Photon & $80.03 \pm 28.67$ & 43.75 & 115.06 \\
\hline \multicolumn{2}{|l}{ *arithmetic mean; " "Standard deviation of mean }
\end{tabular}


represent accuracy; however, the standard deviation distribution was distinct (0.015), which means that precision was different among the 3D printers. Fig. 2 shows images of superimposed original STL files on $3 \mathrm{D}$ printed models. Colors close to green indicate minimal discrepancy, while red areas indicate regions of greater superimposition. Fig. 3 shows the prevalence of discrepancies according to tooth surface.

\section{DISCUSSION}

Accuracy did not differ among the tested 3D printers, ranging from $52.97 \pm 20.48$ to $80.03 \pm 28.67$ $\mu \mathrm{m}$. These values are consistent with the resolutions indicated by the manufacturers. Considering the distribution of these values, we can infer that is possible that all 3D printers can reproduce details in accordance with the ISO 6873 requirements for dental gypsum products, which establish a minimum detail reproduction of $75 \pm 8 \mu \mathrm{m}$ for types 1 and 2 dental materials and of $50 \pm 8 \mu \mathrm{m}$ for gypsum types 3,4 , and 5 . The variability, given by the standard deviation, refers to the precision of the 3D printers, indicating that the most precise printer (the one with the lowest standard deviation for the mean value of discrepancy among models revealed by Levene test) was the one manufactured by Straumann.

The differences in precision could be related to the distinct resolutions, especially in the $\mathrm{Z}$ plane ${ }^{4}$.

\section{FUNDING}

None
Larger deviations associated with the 3D printed model may be due to the thickness and shrinkage between the layers of the material that occur in the $\mathrm{Z}$ plane and to contraction of the material caused by post-curing ${ }^{4}$. The shrinkage in the $\mathrm{Z}$ plane may also be the cause of the higher prevalence of discrepancies on the incisal surface of the preparation. Positive discrepancies in this region, even without causing marginal misfit of prosthetic parts, may compromise the longevity of the restoration as a result of greater thickness of the cement line.

The large standard deviations of discrepancy values should be considered upon evaluation of the data presented. They are related to the precision of the printer, but random errors of methods used could also be present. Thus, the data presented in this study should be considered cautiously. Future clinical studies are welcome to evaluate the efficacy of oral rehabilitations where digital workflow is part of treatment.

Overall, all tested 3D printers appear to have sufficient accuracy and precision to be used in the digital workflow for patient rehabilitation. However, it should be noted that 3D printers with lower precision are more likely to lead to the misfit of prosthetic parts and consequently, to rework.

\section{CONCLUSION}

The printers had distinct precision but did not differ in accuracy.

\section{CORRESPONDENCE}

Dr. Fernando Portella

Rua Residencial Village 7B, Esteio, RS, Brazil. CEP 93265-230.

portellaff@yahoo.com.br

3. Alharbi N, Wismeijer D, Osman RB. Additive Manufacturing Techniques in Prosthodontics: Where Do We Currently Stand? A Critical Review. Int J Prosthodont 2017; 30:474-484.

4. Sim JY, Jang Y, Kim WC, Kim HY, Lee DH, Kim JH. Comparing the accuracy (trueness and precision) of models of fixed dental prostheses fabricated by digital and conventional workflows. J Prosthodont Res 2019; 63:25-30. 


\title{
Use of Antibiotics in early Childhood and Dental Enamel Defects in 6- to 12-year-old Children in Primary Health Care
}

\author{
Daniel D. Faustino-Silva', Ariston F. Rocha', \\ Bruno S. da Rocha'2, Caroline Stein ${ }^{3}$ \\ ' Grupo Hospitalar Conceição - Serviço de Saúde Comunitária; Programa \\ de Pós-Graduação em Avaliação de Tecnologias para o Sistema Único \\ de Saúde (SUS), Rio Grande do Sul, Brasil. \\ 2 Universidade Federal do Rio Grande do Sul, Hospital de Clínicas de Porto Alegre, \\ Programa de Pós-graduação em Ciências Médicas: Endocrinologia, \\ Rio Grande do Sul, Brasil. \\ ${ }^{3}$ Universidade Federal do Rio Grande do Sul, Programa de Pós-graduação \\ em Odontologia, Rio Grande do Sul, Brasil.
}

\begin{abstract}
Dental enamel defects (DED) are lesions that occur due several factors. Proper care is needed to promote their treatment and prevention. The aim of this study was to evaluate the occurrence of DED in permanent teeth of children who used antimicrobial drugs in the first four years of life. This is a crosssectional study carried out in a Primary Health Care (PHC) service, which included children from six to 12 years of age. $D E D$ were evaluated by oral examination, and data on the use of antimicrobials in early childhood were collected based on medical records. Data were analyzed with the chi-square test and Fisher's exact test. The sample included 144 children. In relation to DED, $50 \%$ (72) and $20.1 \%$ (29) presented opacity
\end{abstract}

and hypoplasia, respectively. Amoxicillin was the most frequently prescribed drug, followed by sulfamethoxazole + trimethoprim. Among the children, 78.5\% (113) were prescribed antimicrobial drugs at least once during the first 4 years of life, and 55\% (79) of them presented some type of DED. There was no statistically significant association between the variables analyzed. In conclusion, there was high prevalence of children with DED, and amoxicillin was the most commonly prescribed antibiotic.

Received: December 2019; Accepted: January 2020

Keywords: dental enamel hypoplasia, primary health care, anti-bacterial agents, amoxicillin, oral health.

\section{Uso de antibióticos na primeira infância e defeitos de esmalte dentário em crianças de 6 a 12 anos na Atenção Primária à Saúde}

\section{RESUMO}

Os defeitos do esmalte dentário (DED) são lesões que ocorrem devido a vários fatores e é necessária atenção para promover seu tratamento e prevenção. O objetivo foi avaliar a ocorrência de DED em dentes permanentes de crianças que usaram antimicrobianos nos primeiros quatro anos de vida. Trata-se de um estudo transversal realizado em um serviço de Atenção Primária à Saúde (APS), que incluiu crianças de seis a 12 anos de idade. A DED foi avaliada por dados de exames bucais, $e$ os dados sobre o uso de antimicrobiano na primeira infância foram coletados com base em prontuários médicos. A análise foi realizada com o teste do qui-quadrado e o teste exato de Fisher. A amostra foi composta por 144 crianças. Em relação

\section{INTRODUCTION}

Once dental enamel has formed, it lacks metabolic activity, which means that any disorders that occur during its development may be manifested as ao DED, 50\%(72) e 20,1\%(29) apresentaram opacidade e hipoplasia, respectivamente. A amoxicilina foi o medicamento prescrito com mais freqüencia, seguido pelo sulfametoxazol+ trimetoprim. Entre as crianças, 78,5\%(113) receberam medicamentos antimicrobianos pelo menos uma vez nos primeiros 4 anos de vida e 55\%(79) deles apresentaram algum tipo de DED. Não houve associação estatisticamente significante entre as variáveis analisadas. Em conclusão, houve uma alta prevalência de crianças com DED e a amoxicilina foi o antibiótico mais comumente prescrito.

Palavras-chave: hipoplasia do esmalte dentário, atenção primária à saúde, antibacterianos, amoxicilina, saúde bucal.

permanent defects in erupted teeth ${ }^{1}$. Such enamel defects are changes that may affect one tooth only or a group of similar teeth, in both dentitions ${ }^{2}$. Disorders in the early secretory phase of the 
amelogenesis matrix are likely to appear as quantitative or morphological defects (hypoplasia), whereas interruptions in the processes of calcification or maturation may produce morphologically normal enamel which is nevertheless structurally or qualitatively defective (hypomineralization/ hypomaturation) ${ }^{1}$. Any systemic, local or genetic factor that may affect the ameloblasts may cause defects on the surface of the dental enamel ${ }^{3}$.

A major change is Molar-Incisor Hypomineralization (MIH), defined as a change in systemic etiology that affects one, two, three or all first permanent molars and permanent incisors ${ }^{2}$. Clinically, hypomineralization is seen as translucency and opacity of the enamel, well defined and not diffuse, which distinguishes it from fluorosis. Hypomineralized enamel has a porous, smooth, chalk-like consistency. Defect in coloring ranges from white to yellow-brown and may be easily differentiated from normal enamel ${ }^{3}$. The exact systemic nature of the lesion has not been fully explained, but disorders during pregnancy, some childhood illnesses and the frequent use of antimicrobials are conditions that are involved in this process. In addition, recent studies have concluded that genetic variations related to amelogenesis are associated with the possibility of developing $\mathrm{MIH}^{4,5}$. It should be noted that ameloblasts are very sensitive cells and the occurrence of any change during enamel maturation may lead to loss of tissue quality, causing defects such as hypomineralization ${ }^{6}$.

The investigation of MIH etiology has focused on environmental accidents that occur during the 3 first years of life, which is the critical period for the formation of permanent molars and incisors ${ }^{6}$. Children with enamel defects have 15-fold higher chances of developing cavities than patients without this type of defect 7 . In addition, the first hypomineralized permanent molars are subject to enamel breakage after tooth eruption due to chewing forces $^{8}$. Hypersensitivity is another common complication of MIH, making oral hygiene and eating more difficult, in addition to further compromising defective teeth, and possibly compromising the clinical management of $\mathrm{MIH}^{9}$. Solving this problem and its possible consequences can be a major challenge involving complex treatments.

Some studies show an association between the use of medicines, especially antimicrobials, and the development of MIH. One study investigated a disease related to $\mathrm{MIH}$, to ascertain whether this association is due to the disease itself or to the drug used to treat it, finding an association between the use of amoxicillin in children and the development of $\mathrm{MIH}^{10}$. Another study also suggested this association, reporting that the use of amoxicillin from 6 weeks to 3 months and from 3 to 6 months significantly increases the risk of enamel defects in primary second molars, but that additional studies are needed to prove this association ${ }^{11}$.

It is therefore important to investigate the use of medicines in early childhood in relation to dental alterations, as amoxicillin is one of the most commonly used antibiotics in pediatric patients, including the context of Primary Health Care (PHC). Thus, the aim of this study was to evaluate the association between the occurrence of dental enamel defects (DED) in permanent teeth of 6- to 12-year-old children who used antibiotics in the first 4 years of life at a Primary Health Care service.

\section{MATERIALS AND METHODS}

This is a cross-sectional study carried out in 2014 at two Basic Health Units of the Community Health Service of Conceição Hospital Group (SSC-GHC), located in the city of Porto Alegre, Rio Grande do Sul, Brazil. The present study used oral examination data for DED from another study carried out in 2012 with 228 children with the aim of evaluating the association between asthma and occurrence of caries, erosion, and enamel defects in children ${ }^{12}$. The research project was approved by the GHC Research Ethics Committee under the CAAE number 26083614.7.0000.5530, and the authors abide by the universal declarations and regulations of Brazil (CNS Resolution 466/12).

The study included children aged 6 to 12 years registered at the Health Units, and excluded any children who did not have regular follow-up in their respective units during the first four years of life, or any whose medical records were not found, either because they moved elsewhere or because care to the family was interrupted. All participants provided written informed consent.

In the original study in $2012^{12}$, prevalence was estimated by considering the main oral changes, such as dental caries and enamel defects, found in previous studies ${ }^{13,14}$. Considering the statistical power of $80 \%$ and a p-value for rejection of the null hypothesis of $p<0.05$, a minimum sample of 214 
children was obtained. Out of 1,278 children, 362 children were selected at random and 228 were examined. In 2014, the medical records of 144 children were examined in order to gather information about the use of medicines and the occurrence of infections in early childhood.

The World Health Organization criteria for DED ${ }^{15}$ were used. The modified DED index is a scale of 0 to 9 which considers enamel normality, presence of opacity (marked, diffuse, or both), presence/ absence of hypoplasia, presence of other defects, presence of all conditions simultaneously or possibility of nonexistent records, according to the following codes: (0) Normal, (1) Marked opacity, (2) Diffuse opacity, (3) Hypoplasia, (4) Other defects, (5) Marked and diffuse opacities, (6) Marked opacity and hypoplasia, (7) Diffuse opacity and hypoplasia, (8) All three conditions and (9) No record.

Two dental surgeons were trained and then calibrated using photographs of the clinical conditions under study ${ }^{16,17}$. The Kappa correlation coefficient was used in the two calibrations to assess concordance between the images evaluated by the same examiner and between examiners. Intra-examiner 1, intraexaminer 2 and inter-examiner Kappa values were $1.00,0.85$ and 0.70 , respectively.

The examinations were performed at the Health Units or at home visits with the aid of a mouth mirror under artificial lighting. To assess the frequency of infections and use of medicines, data were collected from the medical records of the children examined who had at least one visit at their health unit from the first months of life and over their first 4 years.

Data were collected by a pharmacist in 2014 from hardcopy medical records at the health units. A structured instrument was used to collect appointment data, patient age at the time of the appointment, drugs used according to the Anatomical Therapeutic Chemical international coding; defined daily dosage; and time of treatment (when reported in the medical record). Information on the reasons for

Table 1: Frequency of drug prescription in the first 4 years of life of 6- to 12-year old children in Primary Health Care, Porto Alegre - RS, $2014(n=144)$.

\begin{tabular}{|c|c|c|c|c|}
\hline Drug & ${ }^{1 s t}$ year $N(\%)$ & ${ }^{2 n d}$ year $N(\%)$ & 3rd year $N(\%)$ & ${ }^{\text {4th }}$ year $\mathrm{N}(\%)$ \\
\hline Amoxicillin & $45(31.2)$ & $52(36.1)$ & $33(22.9)$ & $42(29.2)$ \\
\hline Amoxicillin + clavulanate & $4(2.8)$ & $1(0.7)$ & $3(2.1)$ & $1(0.7)$ \\
\hline Ampicillin & $4(2.8)$ & $1(0.7)$ & $4(2.8)$ & $1(0.7)$ \\
\hline Azithromycin & $3(2.1)$ & $2(1.4)$ & $7(4.9)$ & $11(7.6)$ \\
\hline Benzylpenicillinbenzathine & $3(2.1)$ & $6(4.2)$ & $8(5.6)$ & $7(4.9)$ \\
\hline Benzylpenicillin potassium & $1(0.7)$ & $1(0.7)$ & $2(1.4)$ & $1(0.7)$ \\
\hline Benzylpenicillin procaine & $3(2.1)$ & $2(1.4)$ & $2(1.4)$ & $2(1.4)$ \\
\hline Cefaclor & $1(0.7)$ & $0(0.0)$ & $0(0.0)$ & $2(1.4)$ \\
\hline Cefadroxil & $2(1.4)$ & $1(0.7)$ & $1(0.7)$ & $0(0.0)$ \\
\hline Cephalexin & $6(4.2)$ & $2(1.4)$ & $3(2.1)$ & $2(1.4)$ \\
\hline Ceftriaxone & $1(0.7)$ & $0(0.0)$ & $0(0,0)$ & $0(0,0)$ \\
\hline Cefuroxime & $1(0.7)$ & $0(0.0)$ & $1(0.7)$ & $0(0.0)$ \\
\hline Ciprofloxacin & $1(0.7)$ & $0(0.0)$ & $1(0.7)$ & $0(0.0)$ \\
\hline Erythromycin & $4(2.8)$ & $6(4.2)$ & $11(7.6)$ & $5(3.5)$ \\
\hline Gentamicin & $1(0.7)$ & $0(0.0)$ & $0(0.0)$ & $0(0.0)$ \\
\hline Metronidazole & $0(0.0)$ & $4(2.8)$ & $4(2.8)$ & $4(2.8)$ \\
\hline Nystatin* & $19(13.2)$ & $8(5.6)$ & $1(0.7)$ & $0(0.0)$ \\
\hline Nitrofurantoin & $2(1.4)$ & $0(0.0)$ & $0(0.0)$ & $1(0.7)$ \\
\hline Oxacillin & $2(1.4)$ & $0(0.0)$ & $0(0.0)$ & $0(0.0)$ \\
\hline Sulfamethoxazole + trimethoprim & $12(8.3)$ & $17(11.8)$ & $16(11.1)$ & $10(6.9)$ \\
\hline
\end{tabular}


appointments within the children's first 4 years of life was also included.

Concerning enamel defects, the children were classified as having normal teeth, presenting opacities (demarcated and/or diffuse) or presenting enamel hypoplasia. Conditions 4 (other defects) and 9 (No record) were not found among the children selected for the study.

To verify the association between exposure to medicines and the development of DED, chi-square and Fisher's exact tests were used. Associations with $\mathrm{p}$ values $<0.05$ were considered statistically significant. Data were organized and analyzed with the aid of the SPSS software version 16.0 (SPSS Inc, Chicago, IL).

\section{RESULTS}

The sample consisted of 144 children whose average age was 8.7 years. The most frequently prescribed antimicrobial drug during the first four years of life was Amoxicillin, with highest frequency of prescription in the second year, $36.1 \%$ (52), followed by sulfamethoxazole + trimethoprim (Table 1).

Table 2 shows that $70 \%$ (101) of the patients presented some type of DED, classified as opacity (demarcated and/or diffuse) or enamel hypoplasia. Even though there is no statistically significant difference, it can be seen that the patients who had had some episode of infectious disease were a slight majority among those who developed enamel

Table 2: Enamel defects and their relationship with infectious diseases and antimicrobial drug prescription per age group in the first 4 years of life of 6- to 12-year-old children in Primary Health Care, Porto Alegre - RS, $2014(n=144)$.

\begin{tabular}{|c|c|c|c|c|c|c|}
\hline \multicolumn{2}{|c|}{ Infectious disease } & Total N & $\begin{array}{l}\text { Normal teeth } \\
\text { N (\%) }\end{array}$ & $\begin{array}{l}\text { Opacities (demarcated } \\
\text { and/or diffuse) } N(\%)\end{array}$ & $\begin{array}{l}\text { Hypoplasia } \\
\text { N (\%) }\end{array}$ & $\mathbf{P}$ \\
\hline & 144 & $43(29.9)$ & $72(50.0)$ & $29(20.1)$ & & \\
\hline \multirow[t]{2}{*}{$0-1$ year } & No & 64 & $18(28.1)$ & $33(51.6)$ & $13(20.3)$ & 0.923 \\
\hline & Yes & 80 & 25 (31.3) & $39(48.8)$ & $16(20)$ & \\
\hline \multirow[t]{2}{*}{1 - 2 years } & No & 61 & $19(31.1)$ & $32(52.5)$ & $10(16.4)$ & 0.618 \\
\hline & Yes & 83 & $24(28.9)$ & $40(48.2)$ & $19(22.9)$ & \\
\hline \multirow[t]{2}{*}{2 - 3 years } & No & 72 & $25(34.7)$ & $33(45.8)$ & $14(19.4)$ & 0.438 \\
\hline & Yes & 72 & $18(25.0)$ & $39(54.2)$ & $15(20.8)$ & \\
\hline \multirow[t]{2}{*}{$3-4$ years } & No & 71 & $24(33.8)$ & $36(50.7)$ & $11(15.5)$ & 0.341 \\
\hline & Yes & 73 & $19(26.0)$ & $36(49.3)$ & $18(24.7)$ & \\
\hline \multicolumn{2}{|c|}{ Antibiotic Prescription } & Total N & $\begin{array}{l}\text { Normal teeth } \\
\text { N (\%) }\end{array}$ & $\begin{array}{l}\text { Opacities (demarcated } \\
\text { and/or diffuse) N (\%) }\end{array}$ & $\begin{array}{l}\text { Hypoplasia } \\
\text { N (\%) }\end{array}$ & $\mathbf{P}$ \\
\hline \multirow[t]{2}{*}{$0-1$ year } & No & 74 & $22(29.7)$ & $39(52.7)$ & $13(17.6)$ & 0.705 \\
\hline & Yes & 70 & $21(30.0)$ & $33(47.1)$ & $16(22.9)$ & \\
\hline \multirow[t]{2}{*}{$1-2$ years } & No & 77 & $21(27.3)$ & $42(54.5)$ & $14(18.2)$ & 0.479 \\
\hline & Yes & 67 & $22(32.8)$ & $30(44.8)$ & $15(22.4)$ & \\
\hline \multirow[t]{2}{*}{2 - 3 years } & No & 87 & 29 (33.3) & $41(47.1)$ & $17(19.5)$ & 0.539 \\
\hline & Yes & 57 & $14(24.6)$ & $31(54.4)$ & $12(21.0)$ & \\
\hline \multirow[t]{2}{*}{3 - 4 years } & No & 86 & $29(33.7)$ & $42(48.8)$ & $15(17.4)$ & 0.411 \\
\hline & Yes & 58 & $14(24.1)$ & $30(51.7)$ & $14(24.1)$ & \\
\hline \multicolumn{2}{|c|}{$\begin{array}{l}\text { Cumulative of antibiotic } \\
\text { prescriptions }\end{array}$} & Total N & $\begin{array}{l}\text { Normal teething } \\
\qquad \mathrm{N}(\%)\end{array}$ & $\begin{array}{l}\text { Opacities (demarcated } \\
\text { and/or diffuse) N (\%) }\end{array}$ & $\begin{array}{l}\text { Hypoplasia } \\
\text { N (\%) }\end{array}$ & $\mathbf{P}$ \\
\hline \multirow{2}{*}{$\begin{array}{l}\text { Used at some } \\
\text { point }\end{array}$} & No & 31 & $9(6.3)$ & $18(12.5)$ & $4(2.8)$ & 0.461 \\
\hline & Yes & 113 & $34(23.6)$ & $54(37.5)$ & $25(17.4)$ & \\
\hline \multirow[t]{2}{*}{ Used all years } & No & 127 & $39(27.1)$ & $62(43.1)$ & $26(18.0)$ & 0.734 \\
\hline & Yes & 17 & $4(2.8)$ & $10(6.9)$ & $3(2.1)$ & \\
\hline
\end{tabular}


hypoplasia in each age group. In all age groups, the presence of opacity (demarcated and/or diffuse) was not related to the prescription of antimicrobial drugs (Table 2).

In the cumulative analysis of antibiotic prescriptions, $78.5 \%$ (113) of the children had used antibiotics at least once, and among these, 37.5\% (54) had opacities (demarcated and/or diffuse) and 17.4\% (25) presented hypoplasia (Table 2).

Table 3 shows that among patients with defects in enamel development, the most frequently prescribed antimicrobial drug was amoxicillin, with at least 6 patients having used it more than 6 times during their first 4 years of life. Sulfamethoxazole associated with trimethoprim was also prescribed more than 6 times in this age group in at least 1 patient. It is also worth mentioning that amoxicillin was the medicine most frequently used by patients without enamel defects.

\section{DISCUSSION}

This study was carried out in the context of Primary Health Care, which provides a children's health program with free access to medical and dental appointments. There are few evaluations of this type in the context of PHC with calibrated examiners for oral evaluation of the patients using a random sample. More than half the patients analyzed presented DED, with opacities and hypoplasia being the most prevalent. In addition to evaluating the prescription of antimicrobials, the study originally intended to evaluate medication timing and dosage. However, one of the difficulties of reviewing medical records is precisely the quality of the records, which can be considered a constraint of the study. Nevertheless, medical records provide more reliable data than the selfreported data provided by mothers regarding the medications used, which would be limited by memory bias.

The international literature reports widely varying prevalence of enamel defects around the world. One study mapped the occurrence of molar-incisor hypomineralization (MIH) in Europe through a questionnaire sent to members of the European

Table 3: Relationship between enamel defects and the frequency of the main antimicrobial drug prescription in the first 4 years of life of 6- to 12-year-old children in Primary Health Care, Porto Alegre - RS, $2014(n=144)$.

\begin{tabular}{|c|c|c|c|c|c|}
\hline Infectious disease & Total & Normal teething & $\begin{array}{l}\text { Opacities (demarcated } \\
\text { and/or diffuse) N (\%) }\end{array}$ & Hypoplasia & $\mathbf{P}^{*}$ \\
\hline Amoxicillin & 144 & 43 & 72 & 29 & 0.442 \\
\hline Less than 4 times & 114 & 35 & 55 & 24 & \\
\hline From 4 to 6 times & 22 & 6 & 14 & 2 & \\
\hline More than 6 times & 8 & 2 & 3 & 3 & \\
\hline Cephalosporin & 144 & 43 & 72 & 29 & - \\
\hline Less than 4 times & 144 & 43 & 72 & 29 & \\
\hline Penicillin & 144 & 43 & 72 & 29 & 0.698 \\
\hline Less than 4 times & 142 & 43 & 70 & 29 & \\
\hline From 4 to 6 times & 2 & 0 & 2 & 0 & \\
\hline $\begin{array}{l}\text { Sulfamethoxazole } \\
\text { + trimethoprim }\end{array}$ & 144 & 43 & 72 & 29 & 0.595 \\
\hline Less than 4 times & 140 & 43 & 68 & 29 & \\
\hline From 4 to 6 times & 3 & 0 & 3 & 0 & \\
\hline More than 6 times & 1 & 0 & 1 & 0 & \\
\hline Azithromycin & 144 & 43 & 72 & 29 & 0.45 \\
\hline Less than 4 times & 142 & 43 & 71 & 28 & \\
\hline From 4 to 6 times & 2 & 0 & 1 & 1 & \\
\hline Erythromycin & 144 & 43 & 72 & 29 & - \\
\hline Less than 4 times & 144 & 43 & 72 & 29 & \\
\hline
\end{tabular}


Academy of Pediatric Dentistry ${ }^{18}$. Prevalence ranged from 3.6 to $25 \%$, with the great majority of data coming from northern Europe ${ }^{18}$. Another study evaluated the prevalence of enamel defects in permanent teeth of portuguese children of $6(n=$ $799)$ and 12 years of age $(n=800)$ in 1999 , finding that $7.3 \%$ of 6 -year-olds and $7.1 \%$ of 12 -year-olds showed demarcated opacities. Numbers were lower for hypoplasia $(0.3 \% \text { and } 0.6 \% \text {, respectively })^{19}$.

A Brazilian study showed that the prevalence of molar-incisor hypomineralization (MIH) among 5to 12 -year-olds was approximately $20 \%$ in both teething periods. In another study in Brazil, that prevalence was $24.4 \%$ in 3 - to 5 -year-olds ${ }^{20}$. These data show a trend to higher prevalence of DED in the Brazilian population compared to the European, which may be associated to different exposure to etiological factors. Conflicting results can be explained by certain factors such as ethnicity, disease history, socioeconomic level, diet, patient age and presence of pollutants in the region ${ }^{20}$. In addition, a recent study in Brazil with 8- to 12-yearolds found that enamel defects were common in this population, but found no association with pre-, peri- and postnatal factors ${ }^{21}$. In our country, developmental defects of dental enamel have not been sufficiently studied, even though they cause aesthetic problems, dental sensitivity, and are factors leading to predisposition to caries ${ }^{22}$.

The occurrence of infectious disease episodes in the 6- to 12-year-old age group is quite common. In all age groups evaluated, most patients had had some infectious disease in this period resulting in the use of antimicrobial drugs for treatment. In the present study, the most frequently prescribed medicine was amoxicillin, which has been introduced as a broadspectrum antimicrobial drug and has been available in the Brazilian public health system ${ }^{23}$ for the past decades, which coincides with the age of the children participating in the study. Amoxicillin is one of the most commonly used antibiotics in pediatric patients for the treatment of upper respiratory tract infections and especially acute otitis, a common childhood disease that affects more than $80 \%$ of children at least once before they are 3 years old ${ }^{24}$. In addition, otitis was the most common reason for prescription of antibiotics. Amoxicillin was the most frequently prescribed antibiotic for children, followed by cephalosporins and sulfamethoxazole-trimethoprim ${ }^{25}$. The widespread use of amoxicillin during childhood may have a significant impact on oral health ${ }^{26}$.

These results are in line with our study, in which cephalosporins and sulfamethoxazole-trimethoprim were among the most commonly prescribed drugs for children in the first 4 years of life. Sulfamethoxazole-trimethoprim was found to have been prescribed 4 to 6 times in at least 3 patients who developed opacities, and more than 6 times in one patient. However, it was not possible to establish a statistically significant association in any of the cases, which may be because the final sample was reduced by the exclusion criteria. A study in Pakistan evaluated the exposure of 367 children to penicillins and cephalosporins, which are widely used in children and considered low-risk for the development of amelogenesis ${ }^{27}$. The authors found out that $15.4 \%$ of those exposed to amoxicillin and $29.2 \%$ of those exposed to cephalosporins presented hypermineralization of permanent teeth and that the increase in the use of these medicines in the past had a statistically significant association $(\mathrm{p}<0.002)$, especially among those who had used it more than 8 times.

Another study with 147 children with average age 10.7 years investigated whether the use of amoxicillin, penicillin $\mathrm{V}$, cephalosporins, macrolides and sulfamethoxazole-trimethoprim could be associated with the development of molar-incisor hypomineralization (MIH). It found that $52.2 \%$ of the children with molar-incisor hypomineralization (MIH) had used antibiotics in the first year of life, and the condition was more common among children who had used amoxicillin or erythromycin than among those who had not used these drugs. In addition, the use of cephalosporins or sulfamethoxazole-trimethoprim was not correlated with molar-incisor hypomineralization $(\mathrm{MIH})^{10}$. In parallel to the present work, we notice that among the 70 children who had used antibiotics in the first year of life, $49(70 \%)$ presented some enamel defect and amoxicillin was the most frequently prescribed medicine, having been used in $31.2 \%$ of the cases.

Small sample size may be a limiting factor in the study, related to non-statistically significant associations between exposure and the outcomes studied, even though other papers in the literature also show this lack of association ${ }^{6}$. The current study included 144 children whose average age was 8.7 years, and found no significant difference 
between groups regarding use of antibiotics, age at which antibiotics were used for the first time, or average number of treatments. Moreover, there was no significant difference among those who used only erythromycin, penicillin, trimethoprim or some other unspecified antibiotic ${ }^{6}$. However, longitudinal studies with more robust samples may be necessary in order to ascertain such associations and to determine outcomes with the other antimicrobials mentioned in this study, since the literature does not present very consistent data, in general terms, that could support a definitive relationship.

It is possible to conclude that there was a high prevalence of children with DED, mainly opacities. It is therefore extremely important to reinforce the oral health care of this population with preventive and educational actions, since defects in the

\section{ACKNOWLEDGMENTS}

We thank the Community Health Service at Grupo Hospitalar Conceição for their availability and support in conducting this study, and the Graduate Dentistry Program at Federal University of Rio Grande do Sul. CS received financial support from the Coordination for the Improvement of Higher Education Personnel, CAPES-Brazil.

\section{FUNDING}

The present study was supported by Grupo Hospitalar Conceição, Serviço de Saúde Comunitária, Rio Grande do Sul, Brazil.

\section{REFERENCES}

1. Crombie F, Manton D, Kilpatrick N. Aetiology of molarincisor hypomineralization: a critical review. Int J Paediatr Dent 2009; 19:73-83.

2. Silva MJ, Scurrah KJ, Craig JM, Manton DJ et al.. Etiology of molar incisor hypomineralization - A systematic review. Community Dent Oral Epidemiol 2016; 44:342-353.

3. Takahashi K, Correia A de SC, Cunha RF. Molar incisor hypomineralization. J Clin Pediatr Dent 2009; 33:193-197.

4. Jeremias F, Pierri RAG, Souza JF, Fragelli CMBet al. Family-Based Genetic Association for Molar-Incisor Hypomineralization. Caries Res 2016; 50:310-318.

5. Jeremias F, Koruyucu M, Kuchler EC, Bayram M, et al. Genes expressed in dental enamel development are associated with molar-incisor hypomineralization. Arch Oral Biol 2013; 58:1434-1442.

6. Whatling R, Fearne JM. Molar incisor hypomineralization: a study of aetiological factors in a group of UK children. Int J Paediatr Dent 2008; 18:155-162.

7. Oliveira AFB, Chaves AMB, Rosenblatt A. The influence of enamel defects on the development of early childhood caries in a population with low socioeconomic status: a longitudinal study. Caries Res 2006; 40:296-302. development of enamel can lead to the formation of cavities in the long term and thereby a significant loss of dental function, as well as causing aesthetic discomfort. Amoxicillin was the most frequently prescribed antibiotic for infectious diseases affecting children in early childhood, and its use was related, even though not statistically significantly, to the development of opacities and hypoplasia. Amoxicillin is known to be effective in the treatment of several infections, mainly those in the respiratory tract and the ear, and has been widely used in Primary Health Care during the past decades. When it is prescribed, therefore, attention should be given to any potential side effects that may arise, such as the development of enamel defects. Based on this information, physicians should take into account this possible association upon considering the risk-benefit ratio in each case.

\section{CORRESPONDENCE}

Dr. Daniel Demétrio Faustino-Silva

Av. Francisco Trein n ${ }^{\circ} 596$, Porto Alegre, RS,

Brazil CEP 91350-200.

ddemetrio@gmail.com

8. William V, Messer LB, Burrow MF. Molar incisor hypomineralization: review and recommendations for clinical management. Pediatr Dent 2006; 28:224-232.

9. Daly D, Waldron JM. Molar incisor hypomineralisation: clinical management of the young patient. J Ir Dent Assoc 2009; 55:83-86

10. Laisi S, Ess A, Sahlberg C, Arvio P, et al. Amoxicillin may cause molar incisor hypomineralization. J Dent Res 2009; 88:132-136.

11. Hong L, Levy SM, Warren JJ, Bergus GR, et al. Primary tooth fluorosis and amoxicillin use during infancy. J Public Health Dent 2004; 64:38-44.

12. Rezende G, dos Santos NML, Stein C, Hilgert JB et al. Asthma and oral changes in children: associated factors in a community of southern Brazil. Int J Paediatr Dent 2019; 29:456-463.

13. Allazzam SM, Alaki SM, El Meligy OAS. Molar incisor hypomineralization, prevalence, and etiology. Int J Dent 2014; 234-508.

14. Hoffmann RHS, de Sousa M da LR, Cypriano S. Prevalence of enamel defects and the relationship to dental caries in deciduous and permanent dentition in Indaiatuba, Sao Paulo, Brazil. Cad Saude Publica 2007; 23:435-444. 
15. WHO. Oral health surveys: basic methods. World Health Organization. Geneva: 4th; 1997. https://apps.who.int/iris/handle/10665/41905

16. Ministry of Health. Examiner Calibration Manual. Brasília: Secretaria de Atenção à Saúde/Secretaria de Vigilância em Saúde. Departamento de Atenção Básica. Coordenação Geral de Saúde Bucal. SB Brasil 2010; 2010.

http://bvsms.saude.gov.br/bvs/publicacoes/pesquisa_nacio nal_saude_bucal.pdf

17. Alves JC, da Silva RP, Cortellazzi KL, Vazquez F de L, et al. Oral cancer calibration and diagnosis among professionals from the public health in Sao Paulo, Brazil. Stomatologija 2013; 15:78-83.

18. Weerheijm KL, Mejare I. Molar incisor hypomineralization: a questionnaire inventory of its occurrence in member countries of the European Academy of Paediatric Dentistry (EAPD). Int J Paediatr Dent 2003; 13:411-416.

19. de Almeida CM, Petersen PE, Andre SJ, Toscano A. Changing oral health status of 6- and 12-year-old schoolchildren in Portugal. Community Dent Health 2003; 20:211-216.

20. Lunardelli SE, Peres MA. Prevalence and distribution of developmental enamel defects in the primary dentition of pre-school children. Braz Oral Res 2005; 19:144-149.
21. Vargas-Ferreira F, Peres MA, Dumith SC, Thomson WM et al. Association of Pre- Peri- and Postnatal Factors with Developmental Defects of Enamel in Schoolchildren. J Clin Pediatr Dent 2018; 42:125-134.

22. Cruvinel VRN, Gravina DBL, Azevedo TDPL, de Rezende CS, et al. Prevalence of enamel defects and associated risk factors in both dentitions in preterm and full term born children. J Appl Oral Sci 2012; 20:310-317.

23. Secretary of Health. Municipal list of essential medicines REMUME. Porto Alegre: Coordenação de Assistência Farmacêutica; 2012. 4 p.

24. Klein JO. Is acute otitis media a treatable disease? Vol. 364, The New England Journal of Medicine. 2011. p. 168-169.

25. McCaig LF, Hughes JM. Trends in antimicrobial drug prescribing among office-based physicians in the United States. JAMA 1995; 273:214-219.

26. Ciarrocchi I, Masci C, Spadaro A, Caramia Get al. Dental enamel, fluorosis and amoxicillin. Pediatr Med Chir 2012; 34:148-154.

27. Tariq A, Alam Ansari M, Owais Ismail M, Memon Z. Association of the use of bacterial cell wall synthesis Inhibitor drugs in early childhood with the Developmental Defects of Enamel. Pakistan J Med Sci 2014; 30:393-397. 